J. ENVIRONMENTAL SYSTEMS, Vol. 30(2) 105-134, 2003-2004

\title{
COMPARISON OF TWO TECHNIQUES TO PROMOTE RECYCLING: BLOCK LEADER VERSUS REWARD
}

\author{
GONZALO DÍAZ MENESES, PH.D. \\ ASUNCIÓN BEERLI PALACIO, PH.D. \\ Universidad de Las Palmas de Gran Canaria
}

\begin{abstract}
This work centers on the study of the recycling adoption making process due to the application of promotion techniques from a immediate perspective: 1) reward technique described as giving a gift to the participants in a promotion program within a lottery; and 2) commitment by block leader technique characterized by the agreeing subject signing a request or statement in which he/she promises to fulfill the conditions of the recycling thanks to the encouragement of a person who belongs to the same social circle. So, we carried out a quasi-experimental work whose results led us to explain the immediate response to these recycling promotion techniques. It contributes to the marketing literature in: 1) understanding the effects of these techniques on people's beliefs and attitudes; and 2) explaining the response to recycling promotion techniques. The practical implications that may stem from these contributions are of an educational nature and for public management of promotion campaigns.
\end{abstract}

\section{INTRODUCTION}

In spite of selective waste collection programs having been in place for some years now, they have not achieved participation of all the public [1-7]. There is no doubt that there must be improvement in the collection channels and programs, and in public participation $[8,9]$. From an academic point of view, for the last 20 years research into recycling behavior has been dominated by the analyses of "applied conduct," wherein incentives and reinforcements are applied in order 
to boost citizen participation and so increase the total amount of material supplied by consumers for recycling. However, there still has not been sufficient research on changes in consumers' recycling beliefs, attitudes, and behavior due to the application of those promotion techniques [10-13], aimed at exploring the alternatives that give rise to maximum receptiveness and response [14] . In any case, the relationships that could be specified in any model should be based on the different associations between cognitive, evaluative, and behavioral variables that appear in the recycling and environmental literature (see Table 1).

The objective of this research is then to explain the different ways of encouraging and strengthening recycling behavior, and to analyze empirically the differences in the effectiveness of two recycling promotion techniques: the "prize technique" and the technique of "commitment with a block leader." This work is structured in four parts: 1 ) a review of the literature, where the hypotheses are set out; 2) a discussion of methodological issues; 3 ) the analysis of the empirical results, which includes an examination of the reliability and validity of the measuring instruments used as well as a study of the results relating to the longitudinal and transversal effects of recycling promotion techniques; and 4) a synthesis of results, academic and professional implications, and limitations and future lines of research.

\section{REVIEW OF THE LITERATURE}

The study of the effects of recycling promotion techniques may begin by defining and classifying the concepts of incentive and reward, since the rigorous study of human conduct must analyze the impact of environmental stimuli on behavior itself [e.g., 15]. To that end, we distinguish two types of effect, depending on whether they precede or follow the desired conduct: incentive and reinforcement [16], whose classification is also referred to in the framework of environmental literature [17-20]. In the recycling context, antecedent or incentive techniques are understood to be reminders, the setting of objectives, explicit commitment, and block leader, while the consequent or reinforcement techniques include reward, information feedback, and punishment [21]. In line with the recycling literature, the reward technique is described as giving a gift to the participants in a promotion program [21], the most common form being a draw. The technique of commitment by block-leader encouragement is characterized by the agreeing subject signing a request or statement in which he promises to fulfill the conditions of the recycling program [17-20]. Thanks to the encouragement of a person who acts as persuader and who belongs to the same social circle [21, 22].

Within the theoretical sphere of attitude, there are two kinds of doctrine about the differential effects of promotion techniques. They concur in recognizing a certain coherence between people's attitudes and behaviors [23]. On the one hand, in order to base the incentive effect on a doctrine, the following theories were 
Table 1. Works that Verify the Association between Cognitive Components, Components of Evaluation and Behavior

\begin{tabular}{|c|c|}
\hline Relations & Trabajos \\
\hline $\begin{array}{l}\text { Ecological conscience } \leftrightarrow \\
\text { Ecological concern }\end{array}$ & $\begin{array}{l}\text { Arcury et al. [49]; Synodinos [76]; Martín y } \\
\text { Siminitrias [77]; Ling-Yee [78]; Bigné [50]; } \\
\text { Fraj et al. [79] }\end{array}$ \\
\hline $\begin{array}{l}\text { Ecological conscience } \leftrightarrow \\
\text { Recycling attitude }\end{array}$ & $\begin{array}{l}\text { McGuiness et al. [54]; Black et al. [55]; } \\
\text { Peattie [56]; Simmons \& Widmar [57]; } \\
\text { Oskamp et al. [58]; Alwitt \& Pitt [59] }\end{array}$ \\
\hline $\begin{array}{l}\text { Ecological conscience } \leftrightarrow \\
\text { Involvement with recycling }\end{array}$ & $\begin{array}{l}\text { McGuiness et al. [54]; Black et al. [55]; } \\
\text { Peattie [56]; Simmons \& Widmar [57]; } \\
\text { Oskamp et al. [58]; Alwitt \& Pitt [59] }\end{array}$ \\
\hline $\begin{array}{l}\text { Ecological conscience } \leftrightarrow \\
\text { Recycling behavior }\end{array}$ & $\begin{array}{l}\text { Dispoto [34]; Fox [80]; Maibach [81]; } \\
\text { Schlegelmilch et al. [82]; Fraj et al. [79] }\end{array}$ \\
\hline $\begin{array}{l}\text { Beliefs about recycling } \leftrightarrow \\
\text { Ecological concern }\end{array}$ & Ransey \& Rickson [83]; Synodinos [76] \\
\hline $\begin{array}{l}\text { Beliefs about recycling } \leftrightarrow \\
\text { Recycling attitude }\end{array}$ & Ransey \& Rickson [83]; Synodinos [76] \\
\hline $\begin{array}{l}\text { Beliefs about recycling } \leftrightarrow \\
\text { Involvement about recycling }\end{array}$ & Ransey \& Rickson [83]; Synodinos [76] \\
\hline $\begin{array}{l}\text { Beliefs about recycling } \leftrightarrow \\
\text { Recycling behavior }\end{array}$ & $\begin{array}{l}\text { Hines et al. [84]; Sia et al. [85]; Howenstine } \\
\text { [9]; Bagozzi \& Dabholkar [28]; Shrum et al. } \\
\text { [13]; Hornik et al. [86] }\end{array}$ \\
\hline $\begin{array}{l}\text { Ecological concern } \leftrightarrow \\
\text { Recycling attitude }\end{array}$ & $\begin{array}{l}\text { Vining \& Ebreo [87]; Derksen \& Gartrell [89]; } \\
\text { Oskamp et al. [88]; Hornik et al. [86]; Minton } \\
\text { \& Rose [90] }\end{array}$ \\
\hline $\begin{array}{l}\text { Ecological concern } \leftrightarrow \\
\text { Involvement with recycling }\end{array}$ & $\begin{array}{l}\text { Vining \& Ebreo [87]; Derksen \& Gartrell [89]; } \\
\text { Oskamp et al. [88]; Hornik et al. [86]; Minton } \\
\text { \& Rose [90] }\end{array}$ \\
\hline $\begin{array}{l}\text { Ecological concern } \leftrightarrow \\
\text { Recycling behavior }\end{array}$ & $\begin{array}{l}\text { Vining \& Ebreo [87]; Derksen \& Gartrell [89]; } \\
\text { Oskamp et al. [88]; Hornik et al. [86]; Minton } \\
\text { \& Rose [90]; Bohlen et al. [51] }\end{array}$ \\
\hline $\begin{array}{l}\text { Recycling attitude } \leftrightarrow \\
\text { Recycling behavior }\end{array}$ & $\begin{array}{l}\text { Lansana [91]; Humphrey et al. [92]; } \\
\text { McCarty [93] }\end{array}$ \\
\hline $\begin{array}{l}\text { Involvement with recycling } \leftrightarrow \\
\text { Recycling behavior }\end{array}$ & Vining \& Ebreo [87]; McCarty \& Shrum [94] \\
\hline
\end{tabular}


considered: the theory of equilibrium [24], the functional theory [25], and the theory of multiple attributes [26]. They all coincide in stating that the transformation of beliefs and evaluations guarantees the development of the desired behavior. In fact, various authors in the recycling literature point out that the commitment technique stimulates the internal behavioral control in a way that places an individual on the verge of collaboration and requires consistency between what is promised and what is done [22, 27]. Similarly, the effectiveness of the block-leader technique is based on the influence of the information supply and on social influence having a direct effect on beliefs and attitudes $[10,28]$.

On the other hand, in order to explain the reinforcement effect, the following theories are available: cognitive dissonance [29], passive learning [30], and attribution [31]. All make it clear that attitudes are frequently modeled on conduct $[32,33]$. Moreover, within the framework of the recycling literature, the effectiveness of the reward technique has been explained on the basis of the instrumental learning theory, which maintains that the systematic guidelines of providing "positive contingencies" increases the frequency of behavior [12]. More specifically, it should be said that the differential effects explained by these two types of theoretical model at bottom consist of the antecedent techniques influencing disposition directly, and behavior indirectly, while the consequent techniques affect behavior directly and dispositions indirectly.

There are two kinds of hierarchy of effects in line with both kinds of doctrine: 1) the classic hierarchy, to explain the response to antecedent techniques; and 2) the low-involvement hierarchy, to interpret the response to consequent techniques. The classic hierarchy of effects is predominant in the interpretation of recycling behavior [34-43]. However, it is possible that the public's interpretation of environmental guidelines is routine and not necessarily ecological [14, 44-46]. Therefore, it can be supposed that there are other hierarchical effects explaining recycling conduct, such as "know-do-feel," relating to habitual and lowcommitment behaviors [47].

The effectiveness of both types of technique is studied starting from the framework of attitude models. Following Lutz [48], we have based ourselves theoretically on the uni-dimensional acceptance of attitude that is identified with people's evaluation and, unlike the tripartite orientation, transfers people's beliefs and intentions or conduct outside the notion of attitude. Based on the environmental literature, we distinguish the following cognitive components: 1) ecological conscience $[49,50]$ and 2) beliefs about recycling $[12,28]$. In addition, there are three evaluative components or attitudes referenced in the literature: 1) ecological concern [51-53], 2) involvement with recycling [54-59]; and 3 ) recycling attitudes [58].

Given the various theoretical models explaining the response to recycling promotion techniques, and in light of the empirical evidence obtained, the following hypotheses are put forward: 
H1: The immediate response to the prize promotion technique and to the promotion technique of commitment with block leader reflects the different models of recycling behavior adoption.

H2: The prize promotion technique and that of commitment with block leader differ in their immediate effectiveness in increasing ecological conscience, ecological concern, recycling attitude and involvement; the block leader technique is the more effective.

Athough there are different models at hand to explain the response to both recycling promotion techniques (reward and commitment with block leader), there appear to be no differences in the immediate increase in recycling, both being highly effective in comparison to other techniques. Particularly in the case of the prize technique, it has been shown that the increase in recycling is more significant than with other reinforcement techniques [17, 44, 60-63], as is the case for raffles or draws [17, 60, 64-67]. These high levels of effectiveness are comparable only to those reached by other antecedent techniques, such as commitment, especially when applied in an individualized way [27, 68-73], and the block leader technique [10, 62, 74].

Accordingly, although different theoretical models can justify the adoption of recycling conduct due to the effect of the type of technique, the promotions comprising giving a gift and encouraging commitment with a block leader could show similar immediate effectiveness in causing the appearance of recycling behavior. Since both techniques require the provision of information about how and where to recycle, it is to be expected that the effects on recycling beliefs do not vary with the type of promotion applied. This suggests the third and fourth hypotheses:

H3: The prize promotion technique and that of commitment with block leader do not differ in their immediate effectiveness in stimulating a recycling response.

H4: The prize promotion technique and that of commitment with block leader do not differ in their immediate effectiveness in increasing the consumers' recycling beliefs.

\section{METHODOLOGICAL ASPECTS}

This research follows a quasi-experimental design and is carried out in natural settings with conveniently constituted groups [75]. Two types of treatment have been designed, comprising the application of the technique of written, individual commitment at the encouragement of a block leader and providing a drawbased prize (see Table 2). These techniques were applied to two different subsamples with a total of 246 volunteers who each selected one member of their respective households as an experimental subject. Each volunteer was responsible 
110 / MENESES AND BEERLI

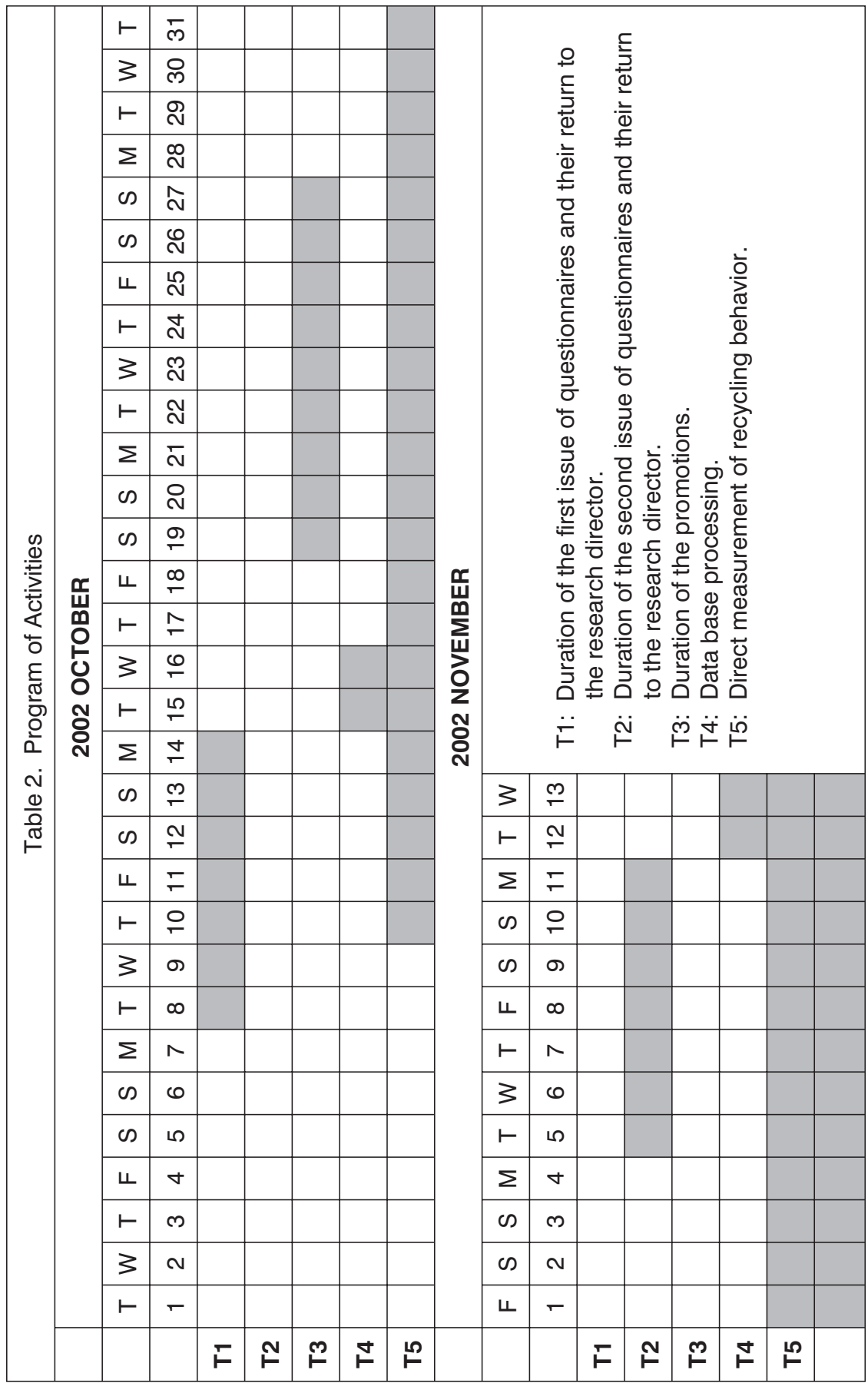


for applying one of the two treatments to that selected member. This procedure of using samples of convenience is recommendable when the collaboration of those surveyed requires, as in the case of this longitudinal research, intensive questionnaire completion. Furthermore, if those surveyed belong to the same social network as the surveyor, there is greater opportunity for observation and control of the individuals in the experiment.

A questionnaire was used to gather the information. The variables and scales were as follows:

1. Ecological conscience, which is defined as information about ecological matters and the causes of ecological damage [49,50], is measured by a Likert scale with four items and 5 points.

2. Beliefs about recycling relative to the knowledge of the how, what, and why of recycling $[12,28]$ is measured by a Likert scale with six items and 5 points.

3. Ecological concern, which is an evaluative component referring to feelings of disquiet about the deterioration of nature [51-53], is measured on a Likert scale with four items and 5 points.

4. Involvement with recycling that refers to a determined degree of concern or interest in recycling [54-59], is measured by a semantic differential scale with four items and 5 points.

5. Recycling attitude is a favorable or unfavorable inclination toward recycling, measured by a semantic differential scale with four items and 5 points [58].

Once the information had been gathered it was entered into the database and refined, eliminating the cases with internal incoherence in which the object of the research had been discovered by the individual being surveyed and those cases in which the individual had stopped participating in the longitudinal study. After eliminating 30 entries, the sample comprised 246 individuals, 123 of whom were assigned to the treatment of subscribing to commitment by block-leader encouragement and 123 to the treatment of possibly receiving a prize by means of a draw.

The recycling materials chosen for this research are: glass, paper and carton, and tetrabrick, metal, or plastic containers. This choice of material was made because it deals with products that: 1) require the active collaboration of the public included in this research; 2) have consolidated distribution channels in our geographical setting, which allows the public to develop the desired behavior without excessive difficulty; 3) are environmentally important from the point of view of sustainability; and 4) are amenable to analysis on the basis of the practical realities of recycling, which are in different stages of evolution because the collection systems were not implemented simultaneously.

The justifications of the choice of the promotion techniques are that: 1) the influence they exert on the consumer differs from the perspective of their 
mechanisms of effectiveness and their effective results in provoking the desired response; 2) they can be applied in an operational way in line with the resources available; and 3) they are representative of the two methods in which they are classified, incentives and reinforcement.

\section{ANALYSIS OF RESULTS}

\section{Preliminaries}

Prior to testing the hypotheses, we checked the validity and reliability of the measuring instruments by means of exploratory factorial, Cronbach's alpha and confirmatory factorial analyses on the cognitive components and the evaluation, ecological, and recycling components. As shown in Table 3, the exploratory factorial analysis with varimax rotation identified all the ecological and recycling characteristics under consideration and explained over $60 \%$ of variance, except in the case of ecological concern, with values of around $50 \%$.

After the exploratory factorial analyses, we proceeded to run a confirmatory factorial analysis in order to check the convergent validity of the same scales. It can be seen in Table 4 that the measuring instruments show a good fit to the data, since in the three series of questionnaires the indicators produce adequate results for the five cognitive, evaluation-of-ecological-character, and recyclingcharacteristic variables. The standardized estimators are significant and positive, with values of above 0.5 in all cases except in the scale referring to ecological concern, with a value of 0.4 .

To study the reliability, an analysis of compound reliability and extracted variance was run, together with Cronbach's alpha. Table 5 shows that all the measuring instruments obtained were above the recommended threshold, except for the extracted variance of ecological concern, which was below that value. Consequently, it can be said that the scales for ecological conscience, recycling beliefs, recycling attitude, and involvement show values that indicate the reliability of the dimensions under consideration, while the scale for ecological concern was close to the critical threshold of 0.40 .

Lastly, in order to check the discriminatory validity of the measuring instruments, a correlations analysis was made which showed that ecological conscience, recycling beliefs, ecological concern, recycling attitude, and recycling involvement measure different ecological and recycling realities, with Pearson's correlation coefficient far below 1 (see Table 6).

To test the hypotheses, a double approximation was performed: the longitudinal or process analysis to study the evolution of the cognitive variables and those of evaluation due to the effect of the promotion technique applied; and the structural or transversal analysis to identify the models that best represent the response to the promotions. 


\section{Transversal Analysis (Hypotheses H1)}

Several alternative Path models were estimated within each of the effect hierarchies being studied, with the aim of selecting those whose specifications best represented the response to each of the recycling promotion techniques. Later, following Gerbing and Andersen [95] and Hair [96], the indicators of the goodness of fit of the two selected types of model were compared in order to choose a final model for each of both promotional subsamples. In the study of response to the promotions, the two subsamples selected were considered: those responding to the prize technique; and those responding to the commitment with block-leader technique.

As Table 7 shows, the transversal analysis of the effectiveness of both types of promotion techniques centered on the study of the measures of goodness of fit proposed by the literature as especially useful in comparing alternative models [97]. It can be seen that low involvement model shows the best fit to the data in all the indicators for the prize subsample. That model corresponds to the hierarchy of effects named, in the terminology of Kotler and Roberto [38], "learn-do-feel," which establishes the sequence of behavior adoption characterized by habits. Furthermore, this kind of model also has the best fit to the data for the subsample of commitment encouraged by a block leader. Therefore, the hierarchies of effects of the most representative models of response to both promotions coincide.

However, to examine the degree of similarity between the two models, it was determined whether statistically significant differences exist by performing a Chi-squared analysis of differences by the multi-group procedure. It can be seen in Table 8 that, although no statistically significant differences exist between the models, significant differences were identified in determined parameters of relationship.

In order to examine the tendency of these differences and after checking that the model without restrictions of equality of regression weights in both sub-samples and the model with those restrictions in both subsamples, except in the two aforementioned relationships, show a good fit to the data (see Table 9), there was an examination of the standardized regression weights and critical ratios of these models. It can be seen that recycling beliefs represent the only possibility of people responding to the prize showing ecological concern, since it is the only link between this variable and the rest of the model. However, in individuals responding to commitment with block leader, this relationship is not significant, although ecological concern plays an important role in relation to other variables since it influences the recycling attitude (see Table 10 and Figure 1).

As a consequence, while recognizing that two significantly different relationships exist in the two models, there is evidence that the process of response to the two types of promotion is quite similar. Therefore, hypothesis H1, stating that the response to the prize promotion technique and to the commitment with block-leader technique is due to models of adopting a recycling behavior, is accepted weakly. 


\begin{tabular}{|c|c|c|c|c|c|c|c|c|c|c|c|c|c|c|}
\hline \multirow{5}{*}{ 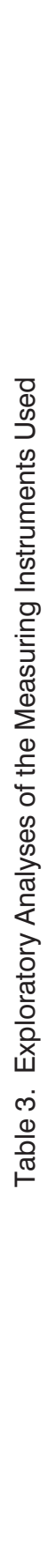 } & \multirow{2}{*}{ 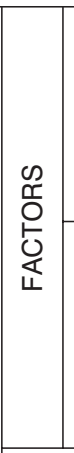 } & $\begin{array}{l}N \\
\mathbb{N} \\
\mathbb{D} \\
\mathbb{0} \\
0\end{array}$ & 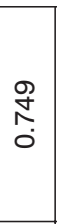 & $\begin{array}{l}\text { O్ } \\
\infty \\
0 \\
0\end{array}$ & $\mid \begin{array}{c}\widetilde{N} \\
\infty \\
0 \\
0 \\
0\end{array}$ & $\begin{array}{l}\hat{\infty} \\
\stackrel{p}{\hat{0}} \\
0\end{array}$ & 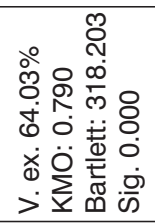 & \multirow{2}{*}{\multicolumn{2}{|c|}{ 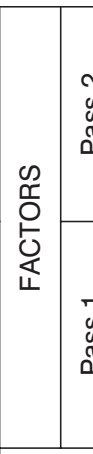 }} & $\mid \begin{array}{l}8 \\
0 \\
0 \\
0 \\
0\end{array}$ & $\begin{array}{l}\stackrel{8}{R} \\
\stackrel{2}{R} \\
0\end{array}$ & 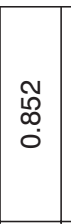 & 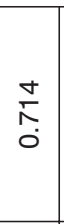 & 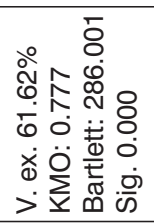 \\
\hline & & $\begin{array}{l}\bar{\Phi} \\
\mathscr{D} \\
\approx \\
0\end{array}$ & $\begin{array}{l}\mathfrak{N} \\
\infty \\
0 \\
0 \\
0\end{array}$ & 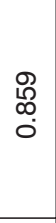 & \begin{tabular}{|c|c|} 
\\
$\infty$ \\
$\infty$ \\
0 \\
0
\end{tabular} & 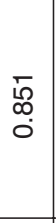 & 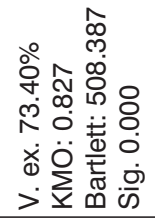 & & $\begin{array}{l}- \\
\infty \\
\mathbb{8} \\
0\end{array}$ & $\left|\begin{array}{l}0 \\
\vdots \\
0 \\
0\end{array}\right|$ & $\begin{array}{l}0 \\
\stackrel{1}{N} \\
0\end{array}$ & $\mid \begin{array}{l}0 \\
\infty \\
0 \\
0\end{array}$ & $\begin{array}{l}\mathcal{M} \\
\stackrel{2}{0} \\
0\end{array}$ & 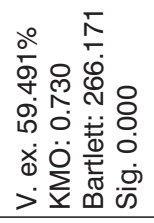 \\
\hline & \multicolumn{2}{|r|}{$\sum_{\underline{E}}^{\infty}$} & 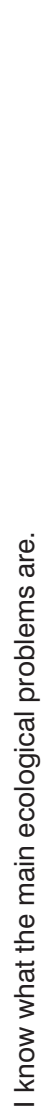 & 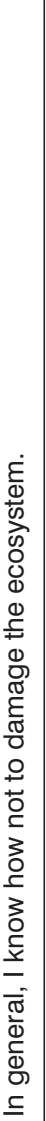 & 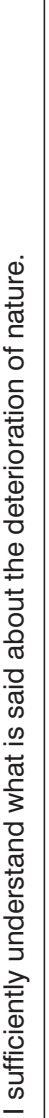 & 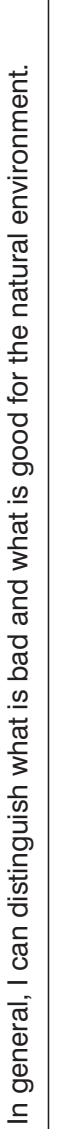 & & & $\sum_{\underline{E}}^{\infty}$ & 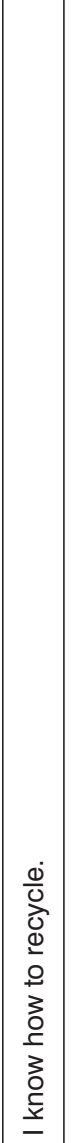 & 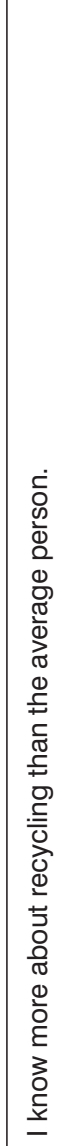 & 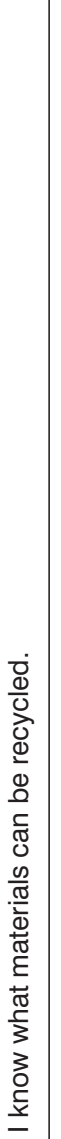 & 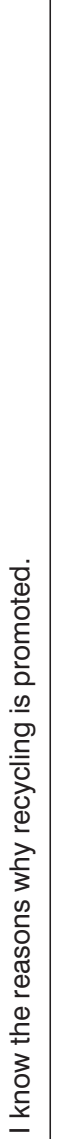 & \\
\hline & & $\stackrel{\dot{x}}{\mathbf{S}}$ & $\tau$ & $\sim$ & $m$ & $\sigma$ & & & 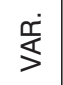 & 10 & 0 & $\wedge$ & $\infty$ & \\
\hline & & & & $\begin{array}{l}\mathrm{N} \text { N } \\
\text { כון }\end{array}$ & $\begin{array}{l}\text { OSNC } \\
\text { 0703 }\end{array}$ & & & & & $\begin{array}{r}\mathrm{yO} \perp 0 \\
\perp \cap 0\end{array}$ & & $\begin{array}{l}\text { DNIT } \\
\text { S } \pm \exists I 7\end{array}$ & $\begin{array}{l}\mathrm{D} \wedge \mathrm{O} \Xi \\
1 \exists \mathrm{g}\end{array}$ & \\
\hline
\end{tabular}


PROMOTING RECYCLING: BLOCK LEADER VERSUS REWARD / 115

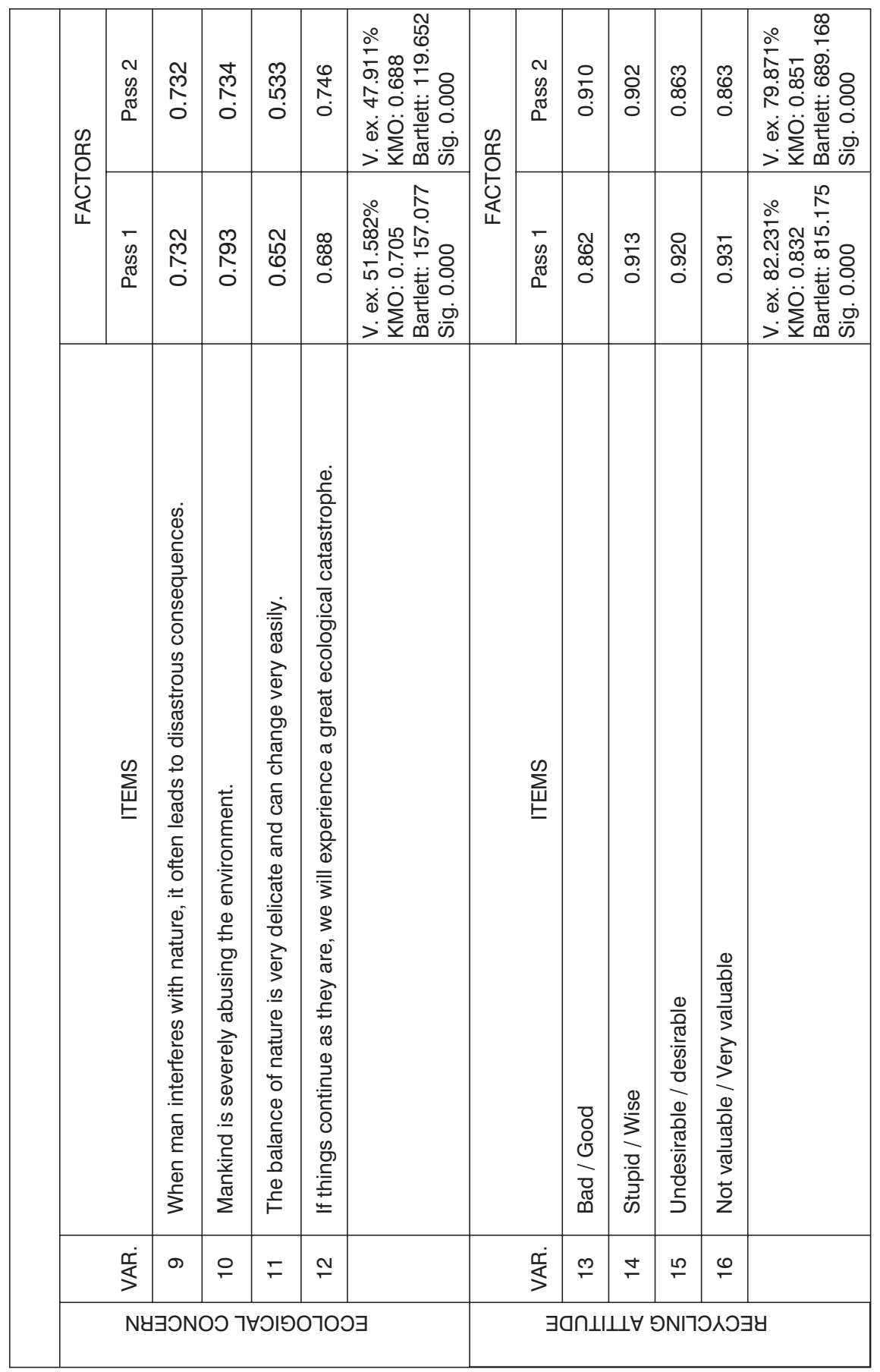




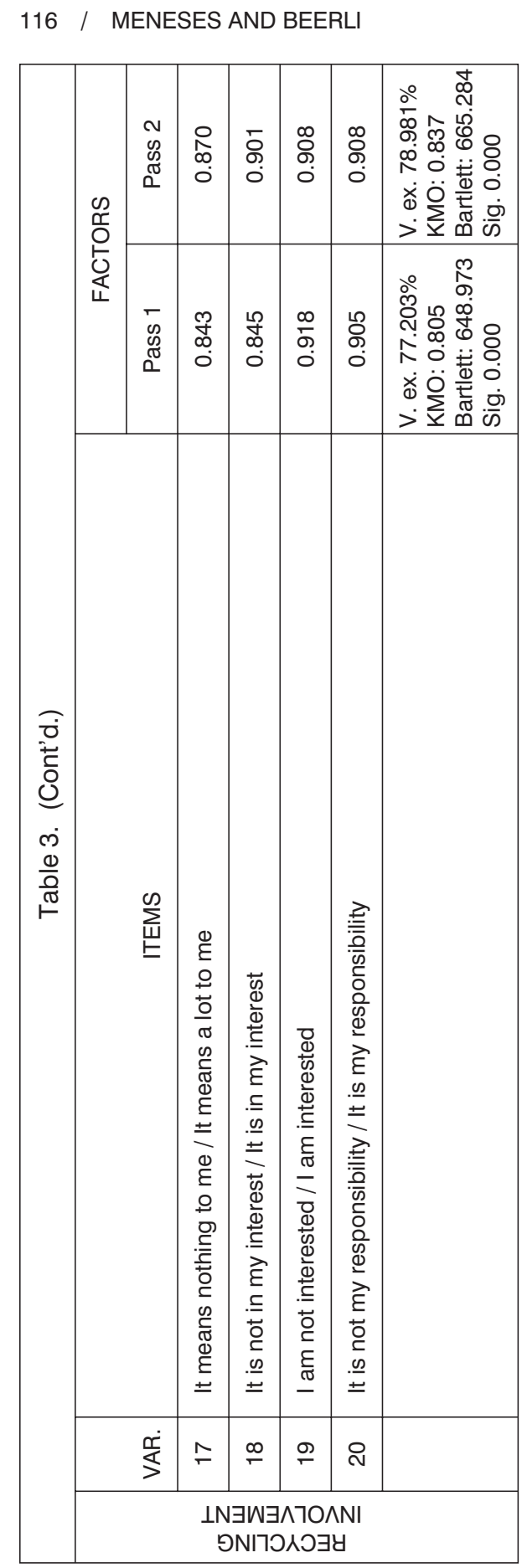




\section{Longitudinal Analysis (H2, H3, and H4)}

For the longitudinal analysis, a Student $t$-test of related samples was first used to identify the intensity, direction, and permanence of the changes in beliefs and ecological and recycling evaluations, as well as in recycling conduct due to the application of promotion techniques. As shown in Table 11, the prize technique has positive and statistically significant effects on recycling beliefs. For their part, ecological conscience and concern decrease immediately after the application of the promotion. Furthermore, the recycling attitude showed no immediate statistically significant transformation. Finally, recycling involvement showed no statistically significant change. The promotion technique of commitment with block leader has positive, statistically significant effects on recycling beliefs, attitude, involvement, and behavior. Lastly, the evolution of ecological conscience and concern followed a similar fall pattern to that produced by the effect of the prize technique.

Before making a comparison of the effectiveness of the two different promotion techniques, there was a student $t$-test of independent samples at moment $\mathrm{t} 1$ in both experimental groups. This was aimed at checking whether there are any statistically significant differences between these variables before the application of the promotion techniques. On the basis of the results obtained, shown in Table 12, it can be concluded that no statistically significant differences exist between the groups regarding the cognitive components and the evaluation and behavior components at moment $\mathrm{t} 1$, or before the promotions were applied.

Finally, in order to test the effectiveness of the two promotion techniques, there was an analysis, based on the General Linear Model (GLM), of repeated measures that determined the differential norms of evolution of the ecological and recycling variables under consideration. From the results shown in Table 13, it can be stated that there is a differential evolutionary effect that depends on the type of promotion technique. This especially applies to recycling involvement and behavior, since the commitment with block-leader technique is much more effective than the prize technique. Similarly, there are no statistically significant differences in the ecological conscience and recycling beliefs immediately after the application of the promotions. Ecological concern diminishes less significantly with the prize technique effect than with the block leader and commitment technique. Lastly, the evolution of recycling attitude presents no differences based on the type of technique implemented.

On the basis of the above, we can conclude that hypotheses $\mathrm{H} 2, \mathrm{H} 3$, and $\mathrm{H} 4$ are contrasted. To be specific, the second hypothesis (H2) - which suggests that the two techniques differ in their effectiveness in increasing ecological conscience and concern and recycling attitude and involvement, in a way that the commitment with block leader technique is more effective-is confirmed, but weakly. This is because, while involvement evolves more markedly from the effect of commitment encouraged by a block leader, attitude shows no statistically 


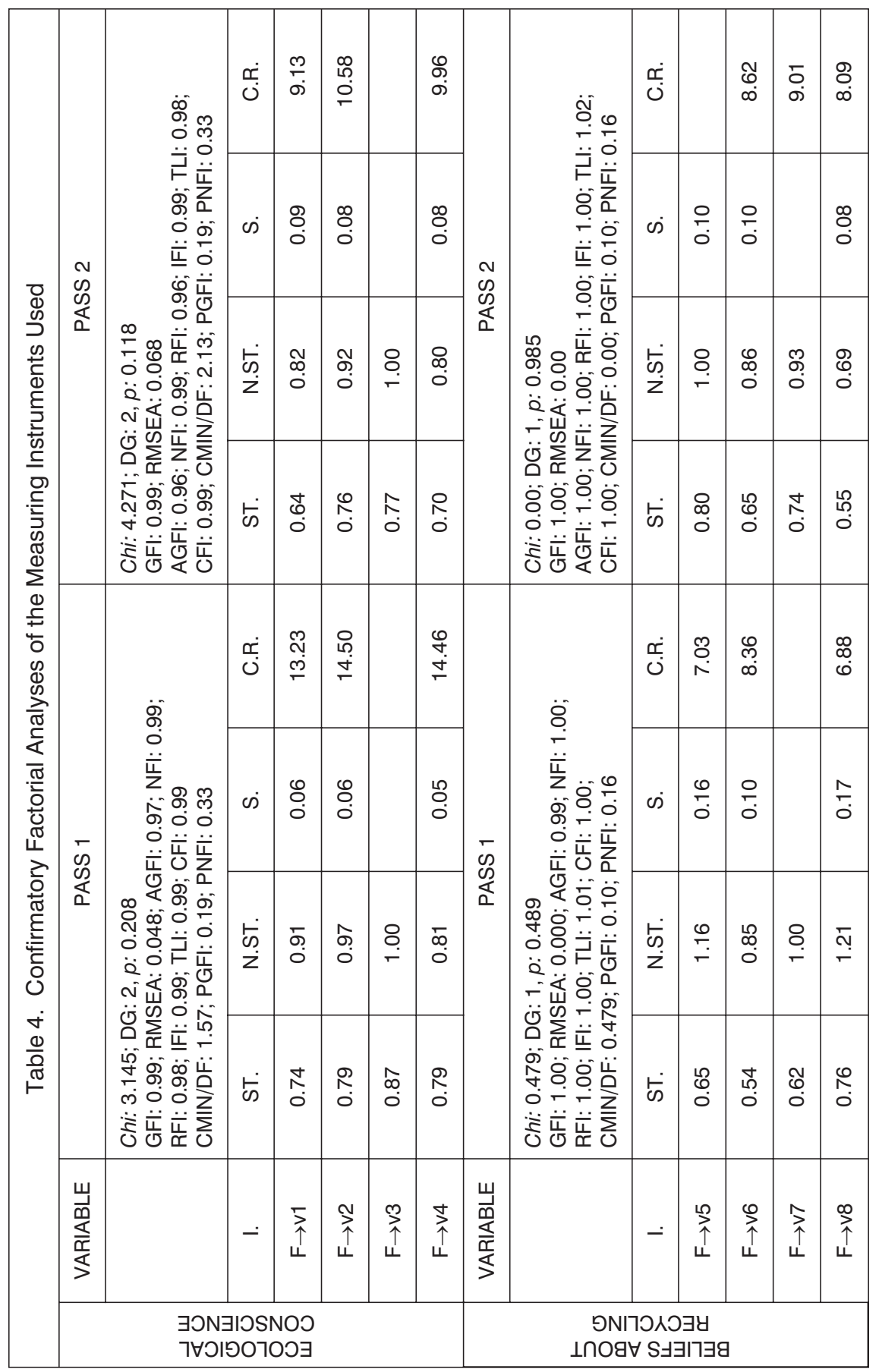


PROMOTING RECYCLING: BLOCK LEADER VERSUS REWARD / 119

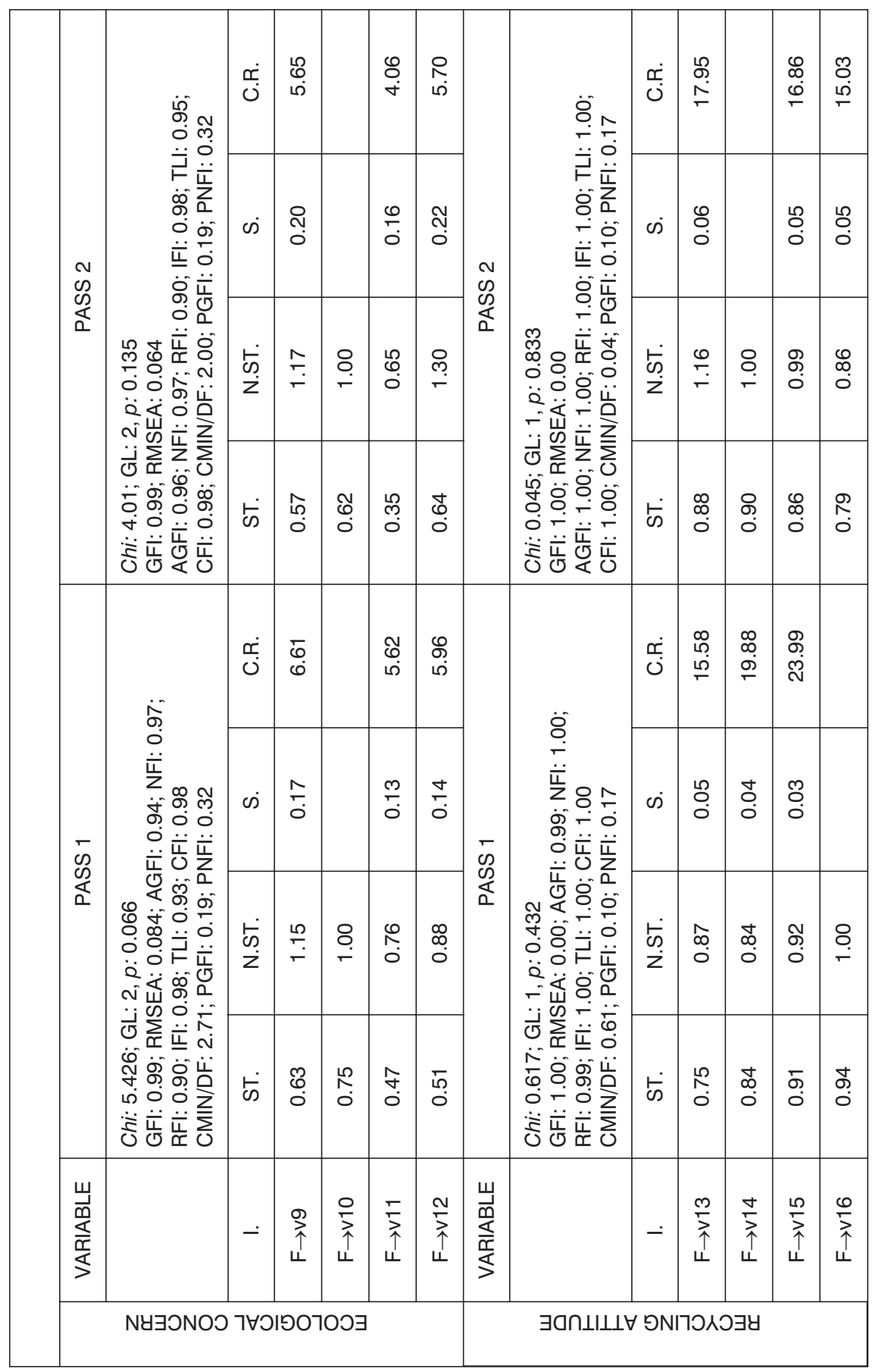


120 / MENESES AND BEERLI

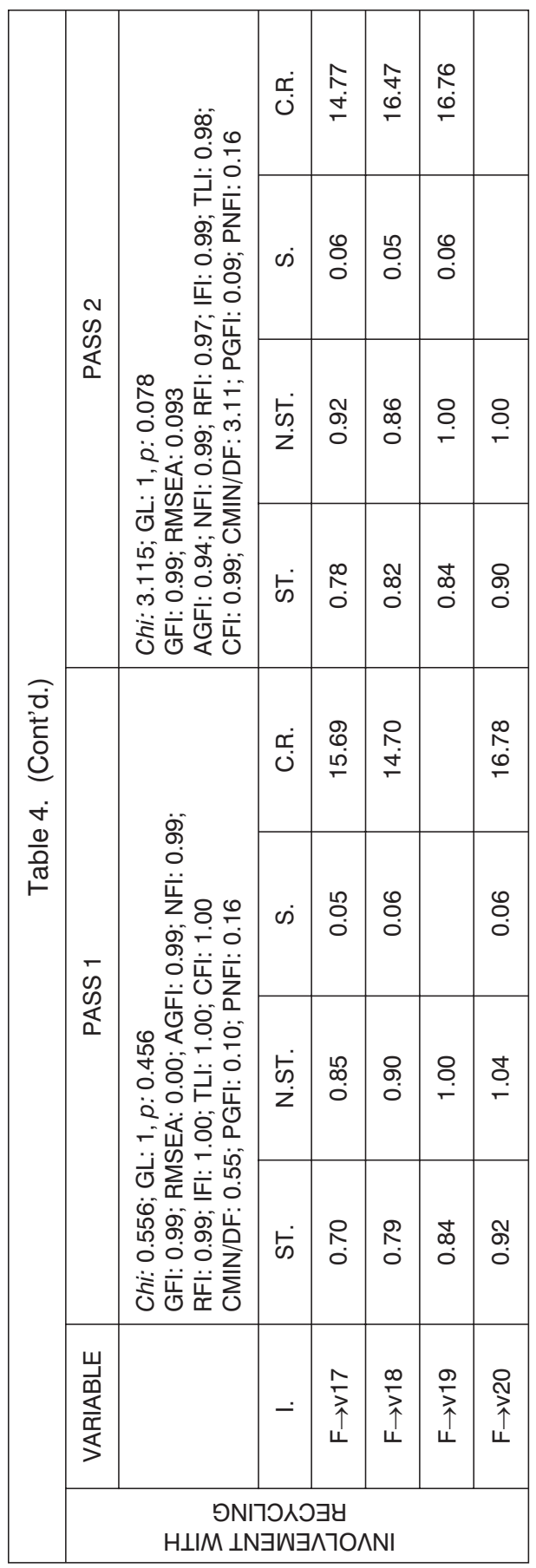


Table 5. Confirmatory Factorial Analysis of the Measuring Instruments Used: Readability Indicators

\begin{tabular}{lccc}
\hline & $\begin{array}{c}\text { Compound } \\
\text { readability }\end{array}$ & $\begin{array}{c}\text { Extracted } \\
\text { variance }\end{array}$ & $\begin{array}{c}\text { Cronbach } \\
\text { alpha }\end{array}$ \\
\hline Ecological conscience & & & \\
$\quad$ Pass 1 & 0.8895 & 0.6689 & 0.8766 \\
Pass 2 & 0.8681 & 0.6232 & 0.8109 \\
Beliefs about recycling & & & \\
$\quad$ Pass 1 & 0.7249 & 0.4010 & 0.7692 \\
Pass 2 & 0.8243 & 0.5444 & 0.7901 \\
Ecological concern & & & \\
Pass 1 & 0.7013 & 0.3781 & 0.6733 \\
Pass 2 & 0.6425 & 0.3198 & 0.6281 \\
& & & \\
Recycling attitude & & & \\
Pass 1 & 0.8689 & 0.6253 & 0.7692 \\
Pass 2 & 0.9088 & 0.7142 & 0.7901 \\
& & & \\
Involvement with recycling & & & \\
Pass 1 & 0.8615 & 0.6110 & 0.9003 \\
Pass 2 & 0.9120 & 0.7222 & 0.9105 \\
\hline
\end{tabular}

significant differences between the two experimental groups and ecological concern shows a significantly greater decrease from the effect of the commitment with block-leader technique.

Hypothesis H3, which proposed that the prize technique and the commitment with block-leader technique do not differ in their effectiveness in stimulating the appearance of the recycling response, is rejected. On the other hand, hypothesis H4-which suggests that the two techniques do not differ in their immediate effectiveness in increasing consumers' recycling beliefs - is confirmed, since recycling beliefs (that is, a knowledge of its practice and meaning) stem not only from the information provided by the promotion techniques but also from the behavior itself.

\section{CONCLUSIONS}

This research contributes to the environmental literature, specifically in the recycling sector, with: 1) the systematization of the set of existing doctrines in order to explain the response to recycling promotion techniques; 2) on understanding the effects of those techniques on people's beliefs and attitudes; and 
122 / MENESES AND BEERLI

Table 6. Correlation Analyses of the Measuring Instruments Used

\begin{tabular}{|c|c|c|c|c|c|c|}
\hline \multicolumn{7}{|c|}{ Pass 1} \\
\hline & & $\begin{array}{l}\text { Ecological } \\
\text { conscience }\end{array}$ & $\begin{array}{l}\text { Beliefs } \\
\text { about } \\
\text { recycling }\end{array}$ & $\begin{array}{l}\text { Ecological } \\
\text { concern }\end{array}$ & $\begin{array}{l}\text { Recycling } \\
\text { attitude }\end{array}$ & $\begin{array}{l}\text { Involvement } \\
\text { with } \\
\text { recycling }\end{array}$ \\
\hline Ecological & Pearson & 1 & & & & \\
\hline conscience & Significance & - & & & & \\
\hline Beliefs about & Pearson & 0.569 & 1 & & & \\
\hline recycling & Significance & 0.000 & - & & & \\
\hline Ecological & Pearson & 0.351 & 0.226 & 1 & & \\
\hline concern & Significance & 0.000 & 0.000 & - & & \\
\hline Recycling & Pearson & 0.253 & 0.402 & 0.159 & 1 & \\
\hline attitude & Significance & 0.000 & 0.000 & 0.012 & - & \\
\hline Involvement & Pearson & 0.352 & 0.437 & 0.239 & 0.451 & 1 \\
\hline with recycling & Significance & 0.000 & 0.000 & 0.000 & 0.000 & - \\
\hline
\end{tabular}

Pass 2

\begin{tabular}{|c|c|c|c|c|c|c|}
\hline & & $\begin{array}{l}\text { Ecological } \\
\text { conscience }\end{array}$ & $\begin{array}{c}\text { Beliefs } \\
\text { about } \\
\text { recycling }\end{array}$ & $\begin{array}{l}\text { Ecological } \\
\text { concern }\end{array}$ & $\begin{array}{l}\text { Recycling } \\
\text { attitude }\end{array}$ & $\begin{array}{l}\text { Involvement } \\
\text { with } \\
\text { recycling }\end{array}$ \\
\hline \multirow{2}{*}{$\begin{array}{l}\text { Ecological } \\
\text { conscience }\end{array}$} & Pearson & 1 & & & & \\
\hline & Significance & - & & & & \\
\hline \multirow{2}{*}{$\begin{array}{l}\text { Beliefs about } \\
\text { recycling }\end{array}$} & Pearson & 0.576 & 1 & & & \\
\hline & Significance & 0.000 & - & & & \\
\hline \multirow{2}{*}{$\begin{array}{l}\text { Ecological } \\
\text { concern }\end{array}$} & Pearson & 0.306 & 0.182 & 1 & & \\
\hline & Significance & 0.000 & 0.004 & - & & \\
\hline \multirow{2}{*}{$\begin{array}{l}\text { Recycling } \\
\text { attitude }\end{array}$} & Pearson & 0.314 & 0.462 & 0.179 & 1 & \\
\hline & Significance & 0.000 & 0.000 & 0.005 & - & \\
\hline Involvement & Pearson & 0.356 & 0.411 & 0.231 & 0.573 & 1 \\
\hline with recycling & Significance & 0.000 & 0.000 & 0.000 & 0.000 & - \\
\hline
\end{tabular}


Table 7. Indicator of the Goodness of Fit of the Four Selected Types of Model to be Compared

\begin{tabular}{lcccccc}
\hline & \multicolumn{7}{c}{ IMMEDIATE EFFECTIVENESS ANALYSIS } \\
& \multicolumn{7}{c}{ Indicators of the prize sub-sample } \\
\cline { 2 - 7 } Models & $P$ & RMSR & ECVI & PNFI & PGFI & AIC \\
\hline Classic Model 1 & 0.636 & 0.006 & 0.838 & 0.066 & 0.048 & 40.223 \\
Habit Model 2 & 0.705 & 0.005 & 0.836 & 0.067 & 0.048 & 40.144 \\
Inverse Model 3 & 0.580 & 0.006 & 0.840 & 0.066 & 0.048 & 40.306 \\
Hedonist Model 4 & 0.029 & 0.008 & 0.933 & 0.063 & 0.046 & 44.773 \\
\cline { 2 - 7 } & Indicators of the commitment with group leader sub-sample \\
\cline { 2 - 7 } & 0.256 & 0.008 & 0.590 & 0.066 & 0.047 & 41.288 \\
Classic Model 1 & 0.762 & 0.003 & 0.573 & 0.067 & 0.048 & 40.091 \\
Habit Model 2 & 0.402 & 0.006 & 0.581 & 0.066 & 0.067 & 40.703 \\
Inverse Model 3 & 0.003 & 0.007 & 0.701 & 0.062 & 0.046 & 49.045 \\
Hedonist Model 4 & & & & & & \\
\hline
\end{tabular}

Table 8. Chi-Square Analysis of Differences by the Multi-Group Procedure: Who Responded to the Prize Technique versus Who Responded to the Commitment with Block Leader Technique

\begin{tabular}{lcc}
\hline Restrictions of equality of regression weights in both sub-samples & CMIN & $p$ \\
\hline Ecological conscience $\rightarrow$ recycling beliefs & 0.165 & 0.862 \\
Ecological conscience $\rightarrow$ behavior & 0.827 & 0.666 \\
Ecological conscience $\rightarrow$ ecological concern & 2.785 & 0.097 \\
Ecological conscience $\rightarrow$ recycling attitude & 0.769 & 0.682 \\
Ecological conscience $\rightarrow$ involvement with recycling & 0.827 & 0.666 \\
Beliefs about recycling $\rightarrow$ behavior & 0.026 & 0.897 \\
Beliefs about recycling $\rightarrow$ recycling attitude & 2.086 & 0.286 \\
Beliefs about recycling $\rightarrow$ involvement with recycling & 0.151 & 0.860 \\
Beliefs about recycling $\rightarrow$ ecological concern & 9.217 & 0.000 \\
Behavior $\rightarrow$ recycling attitude & 1.128 & 0.569 \\
Behavior $\rightarrow$ involvement & 0.561 & 0.738 \\
Ecological concern $\rightarrow$ recycling attitude & 4.317 & 0.041 \\
Ecological concern $\rightarrow$ involvement & 0.602 & 0.730 \\
Recycling attitude $\rightarrow$ involvement & 0.346 & 0.803 \\
$\quad$ - Restrictions of equality of all regressions weights & 20.56 & 0.18 \\
$\quad-$ Restrictions of equality of all regressions weights, except & & \\
$\quad$ in significant parameters & 9.25 & 0.70 \\
\hline
\end{tabular}


124 / MENESES AND BEERLI

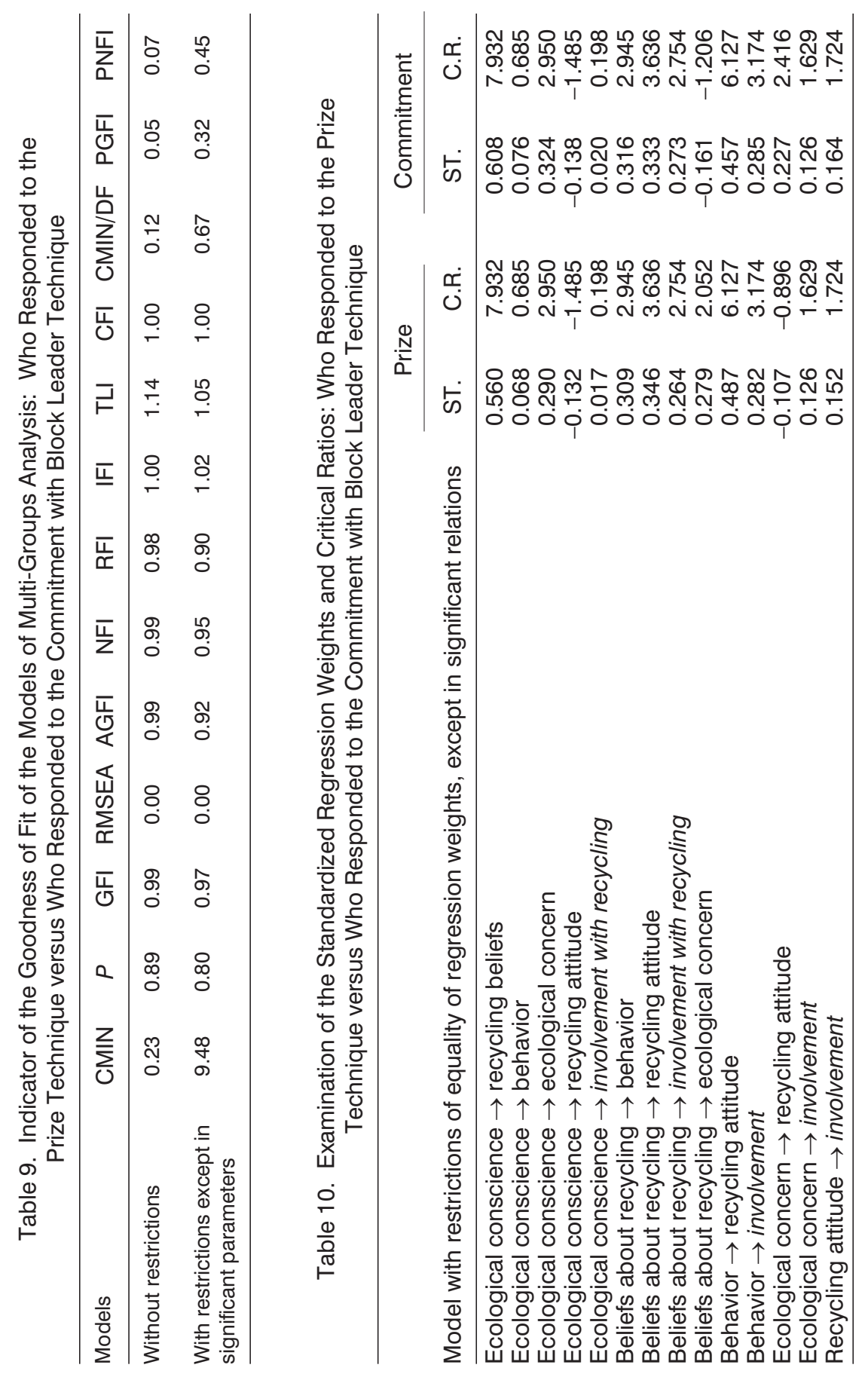


PROMOTING RECYCLING: BLOCK LEADER VERSUS REWARD

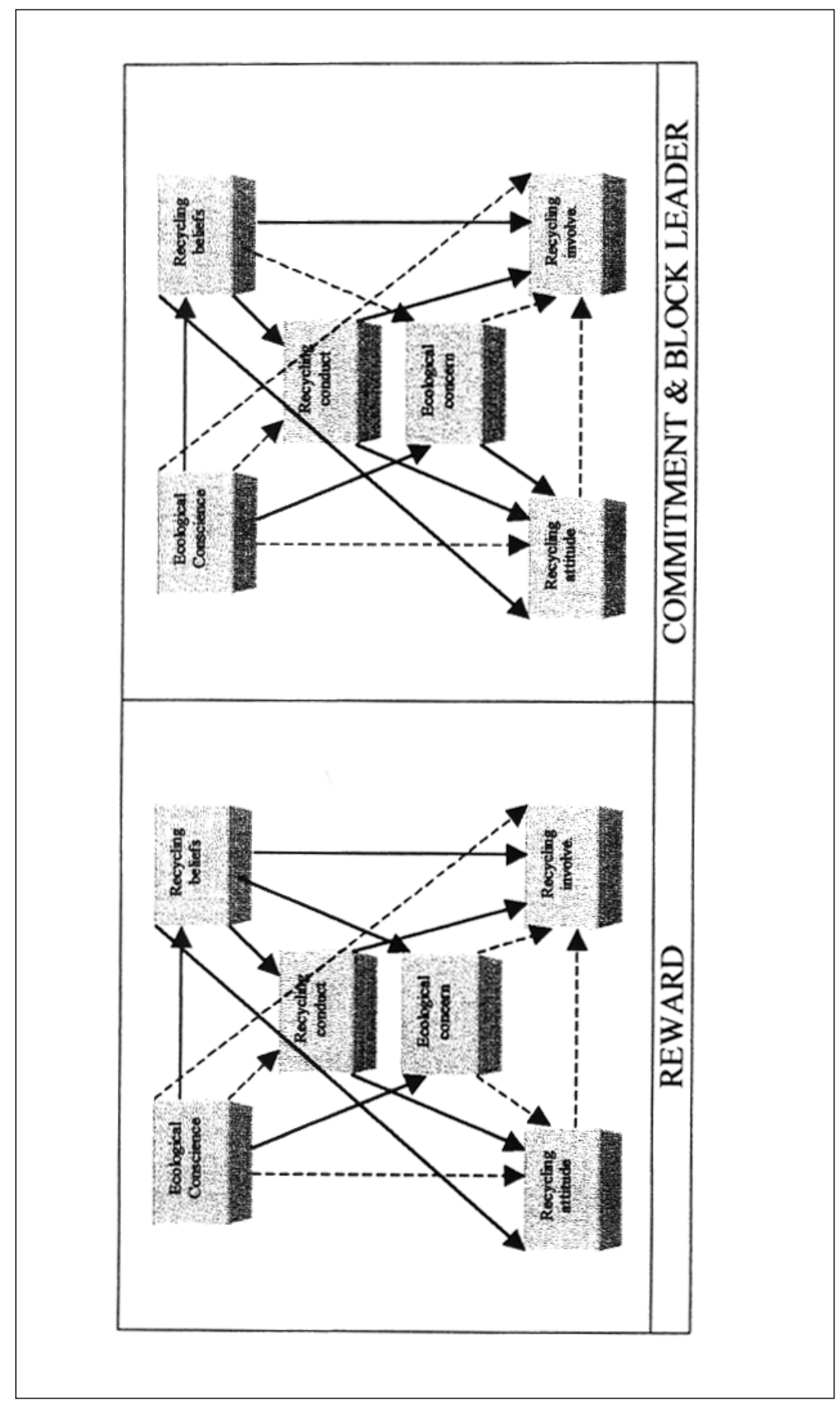

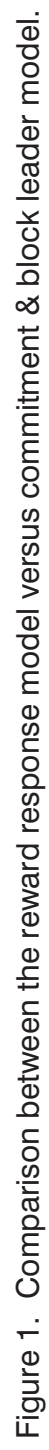


Table 11. Non-Compared Evolution Due to the Effect of the Promotion Techniques: Student $T$-Test for Related Samples

\begin{tabular}{|c|c|c|c|c|c|c|}
\hline & $\mathrm{T} 1$ & $\mathrm{~T} 2$ & Sig. & $S$ & Correlation & Sig. \\
\hline \multicolumn{7}{|l|}{ Prize } \\
\hline Ecological conscience & 3.03 & 2.75 & 0.00 & 0.51 & 0.59 & 0.00 \\
\hline Beliefs about recycling & 2.38 & 2.62 & 0.00 & 0.48 & 0.53 & 0.00 \\
\hline Ecological concern & 2.51 & 2.18 & 0.00 & 0.41 & 0.46 & 0.00 \\
\hline Recycling attitude & 3.02 & 3.13 & 0.13 & 0.84 & 0.63 & 0.00 \\
\hline Involvement with recycling & 3.18 & 3.19 & 0.77 & 0.63 & 0.67 & 0.00 \\
\hline Behavior & 2.39 & 2.56 & 0.01 & 0.78 & 0.80 & 0.00 \\
\hline \multicolumn{7}{|c|}{ Commitment \& Block Leader } \\
\hline Ecological conscience & 2.96 & 2.75 & 0.00 & 0.66 & 0.39 & 0.00 \\
\hline Beliefs about recycling & 2.35 & 2.70 & 0.00 & 0.49 & 0.53 & 0.00 \\
\hline Ecological concern & 2.45 & 2.24 & 0.00 & 0.38 & 0.52 & 0.00 \\
\hline Recycling attitude & 3.04 & 3.28 & 0.00 & 0.68 & 0.73 & 0.00 \\
\hline Involvement with recycling & 3.12 & 3.35 & 0.00 & 0.60 & 0.69 & 0.00 \\
\hline Behavior & 2.20 & 2.79 & 0.00 & 0.92 & 0.65 & 0.00 \\
\hline
\end{tabular}

3) an explanation of the immediate response-making process, considering the effectiveness of both the prize technique and the commitment with block leader technique. Consequently, the practical implications that may stem from these contributions are both of an educational nature and for the public management of promotion campaigns among the public.

From an educational point of view, it has been shown that there are many similarities between the responses to both techniques. So, on the basis of empirical evidence and in line with the low involvement model performed, it seems logical that educators must always make some effort to transmit information about both ecological matters and the how, what, and why of recycling so that pupils gain some ecological conscience and beliefs about recycling. The importance of this lies in the fact that these kinds of knowledge are the main antecedents of recycling behavior. However, in addition to that, environmental educators must consider that there are some significant differences between the effects of offering a reward and those of a commitment with block leader. Those differences are related to the function of ecological concern; while the reward technique does not link this feeling of disquiet about the deterioration of nature to other variables, the commitment with block leader makes good use of this sentiment insofar as it works by consolidating a favorable attitude toward recycling. Therefore, both 
PROMOTING RECYCLING: BLOCK LEADER VERSUS REWARD ／ 127

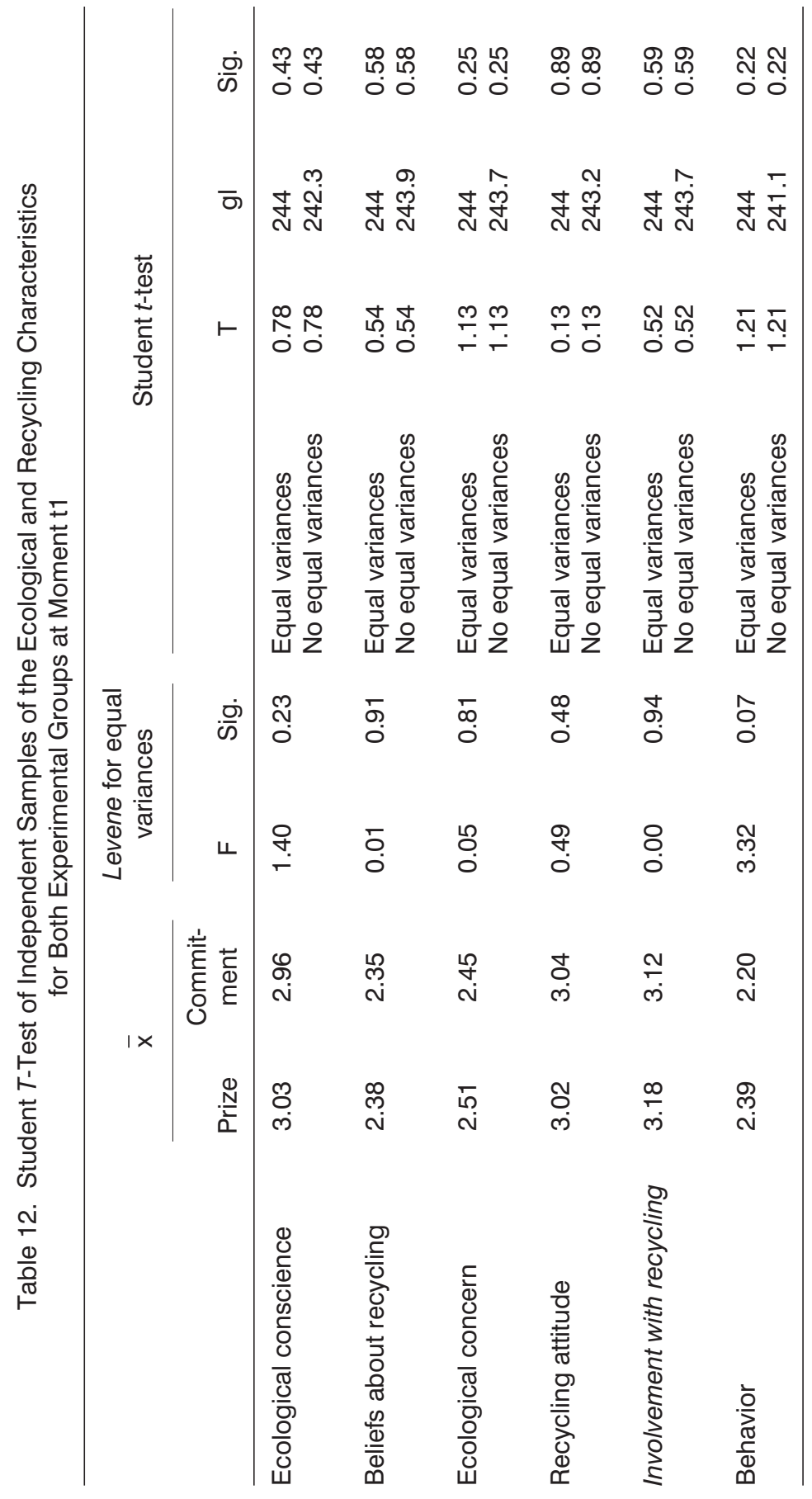


Table 13. General Linear Model of Repeated Measures to Compare the Immediate Effectiveness of Both Types of Promotion

\begin{tabular}{lllllc}
\hline & & & Value & $F$ & Significance \\
\hline Ecological & Immediate & Pillai & 0.003 & 0.763 & 0.383 \\
conscience & effectiveness & Lambda/Wilks & 0.997 & 0.763 & 0.383 \\
& (promotion & Hotelling & 0.003 & 0.763 & 0.383 \\
& factor t1-t2) & Roy & 0.003 & 0.763 & 0.383 \\
Beliefs about & Immediate & Pillai & 0.013 & 3.204 & 0.075 \\
recycling & effectiveness & Lambda/Wilks & 0.987 & 3.204 & 0.075 \\
& (promotion & Hotelling & 0.013 & 3.204 & 0.075 \\
& factor t1-t2) & Roy & 0.013 & 3.204 & 0.075 \\
Ecological & Immediate & Pillai & 0.020 & 4.925 & 0.027 \\
concern & effectiveness & Lambda/Wilks & 0.980 & 4.925 & 0.027 \\
& (promotion & Hotelling & 0.020 & 4.925 & 0.027 \\
& factor t1-t2) & Roy & 0.020 & 4.925 & 0.027 \\
Recycling & Immediate & Pillai & 0.006 & 1.568 & 0.212 \\
attitude & effectiveness & Lambda/Wilks & 0.994 & 1.568 & 0.212 \\
& (promotion & Hotelling & 0.006 & 1.568 & 0.212 \\
& factor t1-t2) & Roy & 0.006 & 1.568 & 0.212 \\
Involvement & Immediate & Pillai & & & \\
with recycling & effectiveness & Lambda/Wilks & 0.028 & 7.104 & 0.008 \\
& (promotion & Hotelling & 0.029 & 7.104 & 0.008 \\
& factor t1-t2) & Roy & 0.029 & 7.104 & 0.008 \\
Behavior & Immediate & Pillai & 0.056 & 14.373 & 0.008 \\
& effectiveness & Lambda/Wilks & 0.944 & 14.373 & 0.000 \\
& (promotion & Hotelling & 0.059 & 14.373 & 0.000 \\
& factor t1-t2) & Roy & 0.059 & 14.373 & 0.000 \\
\hline
\end{tabular}

recycling promotion techniques provoke similar models of cognitive assimilation but different recycling evaluation patterns. In this respect and from a practical point of view, we conclude that in the case of the reward technique ecological concern is worthless but block leaders must include this content in their messages.

From the point of view of the public management of promotion campaigns among the public, and on the basis of our results, we point out that both campaigns are commendable and they must start solely by providing information. Therefore, many programs to encourage recycling behavior can rely upon large-scale information related to ecological conscience and beliefs about recycling. However, it is clear that there are some differences depending on the type of promotion campaign. The increase in recycling behavior and involvement with recycling is more important due to the effect of the block leader with commitment technique since this incentive shows higher levels of effectiveness than the reward technique. 
So, although the block-leader technique is more costly, it could be more interesting because it provokes high involvement processes of adoption in individuals and more collaboration with the selective waste recovery campaign. In fact, those who respond to the commitment technique can be identified as people to be used in the future, true leaders of dissemination or volunteer staff.

Lastly, we would like to propose a future line of research that may stem from this work. This research centers on studying the positive response to every technique but it does not address non-response. However, our results lead one to

think that there must be very different internal barriers depending on the type of technique as long as beliefs about recycling achieve the same level of results after implementing the techniques. In this sense, an in-depth examination of the phenomenon of consumers' reluctance to adopt a recycling behavior, accompanied by an attempt to develop and test specific models of reluctance to recycle that consider the different effects of each promotion technique, could be of great interest.

\section{REFERENCES}

1. W. Zikmund and W. Stanton, Recycling Solid Wastes: A Channel of Distribution Problem, Journal of Marketing Research, 35:3, pp. 34-39, 1971.

2. J. Guiltinon and N. Nwokeye, Developing Distribution Channels and Systems in the Emerging Recycling Industries, International Journal of Physical Distribution, 6:1, pp. 28-38, 1975.

3. J. Barnes, Recycling: A Problem in Reverse Logistics, Journal of Macromarketing, 2:1, pp. 31-37, 1982.

4. T. Pohlen and T. Farris, Reverse Logistics in Plastics Recycling, International Journal of Physical Distribution \& Logistics Management, 22:7, 35-47, 1992.

5. L. González, L. Residuos Sólidos Urbanos. Gestión Municipal y Comercialización de Envases [Urban Solid Residuals: How to Manage Them], Distribución y Consumo, 17, pp. 155-163, 1994.

6. J. Thogersen, A Model of Recycling Behavior, with Evidence from Danish Source Separation Pregrammes, International Journal of Research in Marketing, 11, pp. 145-163, 1994.

7. M. Jahre, Household Waste Collection as a Reverse Channel. A Theoretical Perspective, International Journal of Physical Distribution \& Logistics Management, 25:2, pp. 39-55, 1995.

8. D. Fuller, Recycling Consumer Solid Waste: A Commentary on Selected Channel Alternatives, Journal of Business Research, 6, pp. 17-31, 1978.

9. E. Howenstine, Market Segmentation for Recycling, Environment and Behavior, 251, pp. 86-102, 1993.

10. J. Hopper and J. Nielsen, Recycling as Altruistic Behavior. Normative and Behavioral Strategies to Expand Participation in a Community Recycling Residence, Environment and Behavior, 23:2, pp. 195-220, 1991.

11. F. Leeming, W. Dwyer, B. Porter, and M. Cobern, Outcome Research in Environmental Education: A Critical Review, Journal of Environmental Education, 24, pp. 8-21, 1993. 
12. P. Wesley, S. Oskamp, and T. Mainieri, Who Recycles and When? A Review of Personal and Situational Factors, Journal of Environmental Psychology, 15, pp. 105-121, 1995.

13. L. Shrum, T. Lowrey, and J. McCarty, Recycling as a Marketing Problem: A Framework for Strategy Development, Psychology and Marketing, 11, pp. 393-416, 1994.

14. J. Vining and A. Ebreo, An Evaluation of the Public Response to a Community Recycling Education Program, Society and Natural Resource, 2, pp. 23-36, 1989.

15. F. Skinner, Science and Human Behavior, Macmillan, New York, 1953.

16. J. Reeve, Motivación y Emoción [Motivation and Emotion], McGraw-Hill, Madrid, 2000.

17. E. Geller, J. Chafee, and R. Ingram, Promoting Paper Recycling on a University Campus, Journal of Environmental Systems, 5:1, pp. 39-57, 1975.

18. E. Geller, Applied Behavior Analysis and Social Marketing: An Integration for Environmental Preservation, Journal of Social Issues, 45:1, pp. 17-36, 1989.

19. R. Hutton and F. Markley, The Effects of Incentives on Environment-Friendly Behaviors: A Case of Study, Advances in Consumer Research, 18, pp. 697-702, 1991.

20. W. Dwyer, F. M. Leeming, B. Porter, and J. Jackson, Critical Review of Behavioral Interventions to Preserve the Environment: Research Since 1980, Environment and Behavior, 25, pp. 275-321, 1993.

21. D. McKenzie-Mohr, Fostering Sustainable Behavior, New Society Publisher, Canada, 1999.

22. S. Burn, Social Psychology and the Stymulation of Recycling Behaviors: The Block Leader Approach, Journal of Applied Social Psychology, 21:8, pp. 611-629, 1991.

23. H. Assael, Comportamiento del consumidor [Consumer Behavior], International Thomson Editores, México, 1999.

24. F. Heider, The Psychology of Interpersonal Relations, John Wiley, New York, 1958.

25. D. Katz, The Functional Approach to the Study of Attitudes, Public Opinion Quarterly, 24, pp. 163-204, 1960.

26. M. Fishbein, An Investigation of the Relationships between Beliefs about an Object and the Attitude toward the Object, Human Relations, 16, pp. 233-240, 1963.

27. A. Pardini and R. Katzev, The Effect of Strength of Commitment on Newspaper Recycling. Journal of Environmental Systems, 13, pp. 245-254, 1983.

28. R. Bagozzi and P. Dabholkar, Consumer Recycling Goals and Their Effect on Decisions to Recycle: A Mean End Chain Analysis, Psychology and Marketing, 11, pp. 1-28, 1994.

29. L. Festinger, A Theory of Cognitive Dissonance, Stanford University Press, Stanford, 1957.

30. H. Krugman, The Impact of Television Advertising Learning Without Involvement, Public Opinion Quarterly, 29, pp. 349-356, 1965.

31. D. Bem and H. McConnell, Testing the Self-Perception Explanation of Dissonance Phenomenon: On the Salience of Premanipulation Attitudes, Journal of Personality and Social Psychology, 14, pp. 23-31, 1970.

32. E. Favell, The Power of Positive Reinforcement: A Handbook of Behavior Modification, Charles C. Thomas, Springfield, Illinois, 1977.

33. E. Kazdin, Behavior Modification in Applied Settings, Dorsey Press, Homewood, Illinois, 1980. 
34. G. Dispoto, Interrelationships among Measures of Environmental Activity, Emotionality and Knowledge, Educational and Psychological Measurement, 37, pp. 451-459, 1977.

35. G. Kok and S. Siero, Tin Recycling: Awareness, Comprehension, Attitude, Intention and Behavior, Journal of Economic Psychology, 16, pp. 157-173, 1985.

36. G. Lynne and L. Rola, Improving Attitude-Behavior Prediction Models with Economic Variables: Farmer Actions toward Soil Conservation, The Journal of Social Psychology, 128:1, pp. 19-28, 1988.

37. R. Emmett, Understanding Paper Recycling Within an Institutionally Supportive Setting: An Application of the Theory of Reasoned Action, Journal of Environmental Systems, 19:4, pp. 307-321, 1990.

38. P. Kotler and E. Roberto, Marketing Social, Diez de Santos Editorial, Madrid, 1992.

39. L. Goldenhar and C. Connell, Understanding and Predicting Recycling Behavior: An Application of the Theory of Reasoned Action, Journal of Environmental Systems, 22:1, pp. 91-103, 1993.

40. J. Thogersen, Monetary Incentives and Environmental Concern. Effect of a Differentiated Garbage Fee, Journal of Consumer Policy, 17, pp. 407-422, 1994.

41. S. Taylor and P. Todd, Understanding Household Garbage Reduction Behavior: A Test of an Integrated Model, Journal of Public Policy and Marketing, 14:2, pp. 192-204, 1995.

42. A. Andreasen, Marketing Social Change: Changing Behavior to Promote Health, Social Development, and the Environment, Jossey-Bass Publishers, San Francisco, 1995.

43. S. Kalafatis, M. Pollard, R. East, and M. Tsogas, Green Marketing and Ajzen's Theory of Planned Behavior: A Cross Market Examination, Journal of Consumer Marketing, 16:5, pp. 441-460, 1999.

44. J. Vining and A. Ebreo, What Makes a Recycler? A Comparison of Recyclers and Non Recyclers, Environment and Behavior, 22:1, pp. 55-73, 1990.

45. E. Williams, College Students and Recycling: Their Attitudes and Behaviors, Journal of College Student Development, 32, pp. 86-88, 1991.

46. R. Chan and L. Lau, Antecedents of Green Purchases: A Survey in China, Journal of Consumer Marketing, 17:4, pp. 338-357, 2000.

47. S. Macey and M. Brown, Residential Energy Conservation, the Role of Past Experience in Repetitive Household Behavior, Environment and Behavior, 5:2, pp. 123-141, 1983.

48. R. Lutz, The Role of Attitude Theory in Marketing, in Perspectives in Consumer Behavior (4th Edition), Kassarjian and Robertson (eds.), Prentice Hall, Englewood Cliffs, New Jersey, pp. 317-339, 1991.

49. T. Arcury, T. Johnson, and S. Scollay, Ecological Worldview and Environmental Knowledge: The New Environmental Paradigm, Journal of Environmental Education, 17, pp. 35-40, 1986.

50. E. Bigné, El Consumidor Verde: Bases de un Modelo de Comportamiento [Green Consumer: Keys to Make a Model], Esic-Market, pp. 237-251, 1997.

51. G. Bohlen, B. Schlegelmilch, and A. Diamantopoulos, Measuring Ecological Concern: A Multi-Construct Perspective, Journal of Marketing Management, 9, pp. 415-430, 1993.

52. M. Zimmer, T. Stafford, and M. Royne, Green Issues: Dimensions of Environmental Concern, Journal of Business Research, 30, pp. 63-74, 1994. 
53. S. Grunert and H. Jorn, Values, Environmental Attitudes, and Buying of Organic Foods, Journal of Consumer Marketing, 16, pp. 39-62, 1995.

54. J. McGuiness, P. Jones, and G. Cole, Attitudinal Correlates of Recycling Behavior, Journal of Applied Psychology, 62, pp. 376-384, 1977.

55. J. Black, P. Stern, and J. Elworth, Personal and Contextual Influences on Household Energy Adaptations, Journal of Applied Psychology, 70, pp. 3-21, 1985.

56. K. Peattie, Painting Marketing Education (or How to Recycle Old Ideas), Journal of Marketing Management, 2, pp. 105-125, 1990.

57. D. Simmons and R. Widmar, Motivations and Barriers to Recycling: Toward a Strategy for Public Education, Journal of Environmental Education, 12, pp. 13-18, 1990.

58. S. Oskamp, M. Harrington, T. Edwards, D. Sherwood, S. Okuda, and D. Swanson, Factors Influencing Household Recycling Behavior, Environment and Behavior, 23:4, pp. 494-519, 1991.

59. L. Alwitt and R. Pitts, Predicting Purchase Intentions for an Environmentally Sensitive Product, Journal of Consumer Psychology, 5:1, pp. 49-64, 1996.

60. J. Witmer and E. Geller, Facilitating Paper Recycling Effects of Promos, Raffles and Contests, Journal of Applied Behavior Analysis, 9, pp. 315-322, 1976.

61. P. Luyben and J. Bailey, Newspaper Recycling: The Effects of Rewards and Proximity of Containers, Environment and Behavior, 11:4, pp. 539-557, 1979.

62. D. Hamad, R. Bettinger, D. Cooper, and G. Semb, Using Behavioral Procedures to Establish an Elementary School Paper Recycling Program, Journal of Environmental Systems, 10, pp. 149-156, 1980.

63. L. Needleman and E. Geller, Comparing Interventions to Motivate Work-Site Collection of Home Generated Recyclables, American Journal of Community Psychology, 20, pp. 775-785, 1992.

64. V. Couch, T. Garber, and L. Karpus, Response Maintenance and Paper Recycling, Journal of Environmental Systems, 8:2, pp. 127-137, 1978.

65. P. Luyben and S. Cummings, Motivating Beverage Container Recycling on a College Campus, Journal of Environmental Systems, 11, pp. 235-245, 1981.

66. H. Jacobs and J. Bailey, Evaluating Participation in a Residential Recycling Program, Journal of Environmental Systems, 12, pp. 141-152, 1982.

67. W. Diamond and B. Loewy, Effects of Probabilistic Rewards on Recycling Attitudes and Behavior, Journal of Applied Social Psychology, 21, pp. 1590-1607, 1991.

68. D. McCaul and T. Kopp, Effects of Goal Setting and Commitment on Increasing Metal, Journal of Applied Psychology, 67, pp. 377-379, 1982.

69. S. Burns and S. Oskamp, Increasing Community Recycling with Persuasive Communication and Public Commitment, Journal of Applied Social Psychology, 16:1, pp. 29-41, 1986.

70. R. Katzev and A. Pardini, The Comparative Effectiveness of Reward and Commitment Approaches in Motivating Community Recycling, Journal of Environmental Systems, 17, pp. 93-113, 1987.

71. T. Wang and R. Katzev, Group Commitment and Resource Conservation: Two Field Experiments on Promoting Recycling, Journal of Applied Social Psychology, 20, pp. 265-275, 1990.

72. I. Deleon and R. Fuqua, The Effect of Public Commitment and Group Feedback on Curbside Recycling, Environment and Behavior, 27:2, pp. 233-250, 1995. 
73. W. Bryce, R. Day, and T. Olney, Commitment Approach to Motivating Community Recycling: New Zealand Curbside Trial, The Journal of Consumers Affairs, 31:1, pp. 27-53, 1997.

74. D. Folz, Recycling Program Design, Management and Participation: A National Survey of Municipal Experience, Public Administration Review, 51:3, pp. 222-231, 1991.

75. R. Moreno and J. López, Análisis Metodológico de Investigaciones Experimentales en Psicología [Methodological Analysis for Experimental Research in Psychology], Editorial Alamex, s.a. Madrid, 1985.

76. N. Synodinos, Environmental Attitudes and Knowledge. A Comparison of Marketing and Business Students with Other Groups, Journal of Business Research, 20, pp. 161-170, 1990.

77. B. Martin and A. Simintiras, The Impact of Green Product Lines on the Environment: Does What They Know Affect How They Feel? Marketing Intelligence \& Planning, 13:4, pp. 16-23, 1995.

78. L. Ling-Yee, Effect of Collectivist Orientation and Ecological Attitude on Actual Environmental Commitment: The Moderating Role of Consumer Demographics and Product Involvement, Journal of International Consumer Marketing, 9:4, pp. 31-53, 1997.

79. E. Fraj, I. Grande, and E. Martínez, Las Variables de Actitud y de Conocimiento Como Determinantes del Comportamiento Ecológico, Investigación y Marketing, 77, pp. 32-42, 2003.

80. G. Fox, Building Support for Environmental Initiatives, Public Management, 73, pp. 7-9, 1991.

81. E. Maibach, Social Marketing for the Environment: Using Information Campaigns to Promote Environmental Awareness and Behavior Change, Health Promotion International, 8:3, pp. 209-224, 1993.

82. B. Schlegelmilch, G. Bohlen, and A. Diamantopoulos, The Link between Green Purchasing Decisions and Measures of Environmental Consciousness, European Journal of Marketing, 30:5, pp. 35-55, 1996.

83. C. Ransey and R. Rickson, Environmental Knowledge and Attitudes, Journal of Environmental Education, 8, pp. 10-18, 1976.

84. J. Hines, H. Hungerford, and A. Tomera, Analysis and Synthesis of Research on Environmental Behavior: A Meta Analysis, Journal of Environmental Education, 18, pp. 1-8, 1986.

85. A. Sia, H. Hungerford, and A. Tomera, Selected Predictors of Responsible Environmental Behavior: An Analysis, Journal of Environmental Education, 17, pp. 31-40, 1986.

86. J. Hornik, J. Cherian, M. Madansky, and C. Narayana, Determinants of Recycling Behavior: A Synthesis of Research Results, The Journal of Socio-Economics, 24,:1, pp. 105-127, 1995.

87. J. Vining and A. Ebreo, Predicting Recycling Behavior from Global and Specific Environmental Attitudes and Changes in Recycling Opportunities, Journal of Applied Social Psychology, 22:20, pp. 1580-1607, 1992.

88. S. Oskamp, R. Williams, J. Unipan, N. Steers, T. Mainieri, and G. Kurland, Psychological Factors Affecting Paper Recycling by Business, Environment and Behavior, 26:4, pp. 477-503, 1994. 
89. L. Derksen and J. Gartrell, The Social Context of Recycling, American Sociological Review, 58, pp. 434-442, 1993.

90. A. Minton and R. Rose, The Effects of Environmental Concern on Environmentally Friendly Consumer Behavior: An Exploratory Study, Journal of Business Research, 40, pp. 37-48, 1997.

91. F. Lansana, Distinguishing Potential Recyclers from Non Recyclers: A Basis for Developing Recycling Strategies, The Journal of Environmental Education, 23, pp. 16-23, 1992.

92. C. Humphrey, R. Bord, M. Hammand, and S. Mann, Attitudes and Conditions for Cooperation in a Paper Recycling Program, Environment and Behavior, 9, pp. 107-124, 1977.

93. J. McCarty, A Structural Equation Analysis of the Relationships of Personal Values, Attitudes and Beliefs about Recycling, and the Recycling of the Solid Waste Product, Journal of Business Research, 36, pp. 41-52, 2000.

94. J. McCarty and J. Shrum, The Recycling of Solid Wastes: Personal Values, Value Orientations, and Attitudes about Recycling as Antecedents of Recycling Behavior, Journal of Business Research, 30, pp. 53-62, 1994.

95. D. Gerbing and J. Anderson, An Updated Paradigm for Scale Development Incorporating Unidimensionality and Its Assessment, Journal of Marketing Research, 25, pp. 186-192, 1988.

96. J. Hair, E. Anderson, R. Tatham, and W. Black, Análisis Multivariante [Multivariate Data Analysis with Readings], Editorial Prentice Hall, $5^{\circ}$ Edición, 1999.

97. T. Luque, Técnicas de Análisis de Análisis de Datos en Investigación de Mercados [Statistical Analysis for Market Research], Pirámide, Madrid, 2000.

\section{Direct reprint requests to:}

Gonzalo Díaz Meneses

Universidad de Las Palmas de Gran Canaria

Facultad de Ciencias Económicas y Empresariales

Módulo C, despacho 1.02

35017 Campus de Tafira

The Canary Islands

Spain

e-mail: gdiaz@dede.ulpgc.es 
Copyright of Journal of Environmental Systems is the property of Baywood Publishing Company, Inc.. The copyright in an individual article may be maintained by the author in certain cases. Content may not be copied or emailed to multiple sites or posted to a listserv without the copyright holder's express written permission. However, users may print, download, or email articles for individual use. 